\title{
Ice velocity of Jakobshavn Isbræ, Petermann Glacier, Nioghalvfjerdsfjorden, and Zachariæ Isstrøm, 2015-2017, from Sentinel 1-a/b SAR imagery
}

\author{
Adriano Lemos ${ }^{1}$, Andrew Shepherd ${ }^{1}$, Malcolm McMillan ${ }^{1}$, Anna E. Hogg ${ }^{1}$, Emma Hatton ${ }^{1}$, and Ian Joughin ${ }^{2}$ \\ ${ }^{1}$ Centre for Polar Observation and Modelling, University of Leeds, Leeds, UK \\ ${ }^{2}$ Polar Science Center, Applied Physics Laboratory, University of Washington, Seattle, Washington, USA
}

Correspondence: Adriano Lemos (a.g.lemos14@leeds.ac.uk)

Received: 8 November 2017 - Discussion started: 12 February 2018

Revised: 12 May 2018 - Accepted: 30 May 2018 - Published: 18 June 2018

\begin{abstract}
Systematically monitoring Greenland's outlet glaciers is central to understanding the timescales over which their flow and sea level contributions evolve. In this study we use data from the new Sentinel-1a/b satellite constellation to generate 187 velocity maps, covering four key outlet glaciers in Greenland: Jakobshavn Isbræ, Petermann Glacier, Nioghalvfjerdsfjorden, and Zachariæ Isstrøm. These data provide a new high temporal resolution record (6-day averaged solutions) of each glacier's evolution since 2014, and resolve recent seasonal speedup periods and inter-annual changes in Greenland outlet glacier speed with an estimated certainty of $10 \%$. We find that since 2012, Jakobshavn Isbræ has been decelerating, and now flows approximately $1250 \mathrm{~m} \mathrm{yr}^{-1}(10 \%)$, slower than 5 years previously, thus reversing an increasing trend in ice velocity that has persisted during the last decade. Despite this, we show that seasonal variability in ice velocity remains significant: up to $750 \mathrm{~m} \mathrm{yr}^{-1}(14 \%)$ at a distance of $12 \mathrm{~km}$ inland of the terminus. We also use our new dataset to estimate the duration of speedup periods (80-95 days) and to demonstrate a strong relationship between ice front position and ice flow at Jakobshavn Isbræ, with increases in speed of $\sim 1800 \mathrm{~m} \mathrm{yr}^{-1}$ in response to $1 \mathrm{~km}$ of retreat. Elsewhere, we record significant seasonal changes in flow of up to $25 \%$ (2015) and $18 \%$ (2016) at Petermann Glacier and Zachariæ Isstrøm, respectively. This study provides a first demonstration of the capacity of a new era of operational radar satellites to provide frequent and timely monitoring of ice sheet flow, and to better resolve the timescales over which glacier dynamics evolve.
\end{abstract}

\section{Introduction}

Between 1992 and 2011, the Greenland Ice Sheet lost mass at an average rate of $142 \pm 49 \mathrm{Gtyr}^{-1}$ (Shepherd et al., 2012), increasing to $269 \pm 51 \mathrm{Gt} \mathrm{yr}^{-1}$ between 2011 and 2014 (McMillan et al., 2016). Ice sheet mass balance is determined from the surface mass balance and ice discharge exported from the ice sheet (van den Broeke et al., 2009). In 2005, dynamic imbalance was responsible for roughly two-thirds of Greenland's total mass balance, making an important contribution to freshwater input into the ocean and $0.34 \mathrm{~mm} \mathrm{yr}^{-1}$ to the global sea level rise at that time (Rignot and Kanagaratnam, 2006). Despite the anomalous atmospheric warming events, especially in 2012 (Tedesco et al., 2013), presenting a more spatially extensive and longer lasting surface melt during this period, marine-terminating outlet glaciers in Greenland still contributed with roughly 30\% (2000-2012) of total mass loss (Enderlin et al., 2014). The observed acceleration of many marine-based glaciers in the western and northern regions of Greenland over the last decade may have been driven by rises in air and adjacent ocean temperatures, which enhanced the surface melting and terminus retreat (Holland et al., 2008; Moon et al., 2014, 2015). The associated increases in basal sliding and calving of their ice fronts in turn produce enhanced discharge, leading to dynamical imbalance and additional ice loss (Joughin et al., 2010, 2014). However, acceleration of marine-terminating glaciers is highly variable in space and time (Howat et al., 2010; Moon et al., 2012; Enderlin et al., 2014), due to the geometry of individual glaciers (Felikson et al., 2017), and the high spatial variability in the forcing mechanisms (Jensen et al., 
2016; Carr et al., 2017). This complexity in glacier response challenges efforts to model their future evolution (Joughin et al., 2012; Bondzio et al., 2017) and, thus, frequent and systematic monitoring is essential to understand the processes governing their dynamic stability and contribution so future mean sea level rise (Joughin et al., 2010; Shepherd et al., 2012).

Ice motion measurements are essential for monitoring ice sheet dynamics and ice discharge, and for assessing an ice sheet's mass budget (Joughin et al., 1995). At present, the only way to monitor ice velocity at a continental scale is through satellite imagery. Glacier velocities were first measured using Landsat satellite data acquired during the 1970s through digital optical image comparison (Lucchitta and Ferguson, 1986). Currently, optical images are still largely used for mapping glaciers velocity at large scale (e.g. Dehecq et al., 2015; Fahnestock et al., 2016; Armstrong et al., 2017). However, due to the dependency upon daylight conditions and the limited acquisitions across the polar regions, the use of synthetic aperture radar (SAR) images has become common since the launch of ERS-1 in 1991. In the following decades, these data have been used to monitor dynamic processes occurring across remote areas such as the Greenland and Antarctic ice sheets (Joughin et al., 2010; Rignot and Mouginot, 2012; Nagler et al., 2015; Mouginot et al., 2017). More recently, after the launch by the European Space Agency (ESA) (2017) of the Sentinel 1-a and 1-b satellites, in April 2014 and April 2016, respectively, many key ice margin areas are systematically monitored every 6 to 12 days. This novel dataset provides the opportunity to systematically monitor the dynamical process driving glacier ice velocity over periodic and short temporal scales. Here we use the Sentinel SAR archive to investigate the temporal variation in ice flow since October 2014 at four large outlet glaciers of the Greenland Ice Sheet.

\section{Study areas}

In this study, we map ice velocity of the Jakobshavn Isbræ (JI), Petermann Glacier (PG), Nioghalvfjerdsfjorden (79-G) and Zachariæ Isstrøm (ZI), which are four of the largest marine-based ice streams in Greenland. Combined they contain ice equivalent to $1.8 \mathrm{~m}$ of global sea-level rise (Mouginot et al., 2015; Jensen et al., 2016) and drain $\sim 21.5 \%$ of Greenland's ice (Rignot and Kanagaratnam, 2006; Rignot and Mouginot, 2012; Münchow et al., 2014).

Jakobshavn Isbræ terminates in the Ilulissat Icefjord in western Greenland (Fig. 1a) and is the fastest glacier draining the ice sheet (Enderlin et al., 2014; Joughin et al., 2014). During the late 1990s, the ice tongue experienced successive break-up events and the glacier began to speed up, exhibiting annual increases in speed of $7 \%$ per year from 2004 and 2007 (Joughin et al., 2008a, 2012, 2014). Until 2012 and 2013, the speedup continued, reaching maximum velocities in excess of $17 \mathrm{~km} \mathrm{yr}^{-1}$ (Joughin et al., 2012, 2014). It has been suggested (van de Wal et al., 2015) that the speedup over this period in the southwest of Greenland might be enhanced by anomalously high melting across the ice sheet surface (Tedesco et al., 2013). Jakobshavn Isbræ is susceptible to changes in the adjacent ocean and Holland et al. (2008) have shown that warm water originating in the Irminger Sea likely enhanced basal melting and weakened the floating ice tongue, triggering its break up in 1997. Furthermore, Gladish et al. (2015) showed that the subsequent changes, which occurred between 2001 and 2014, were mainly triggered by changes in Ilulissat Icefjord water temperatures adjacent to the glacier. At present, JI is a tidewater glacier and has a bimodal behaviour, retreating by $\sim 3 \mathrm{~km}$ during summer and advancing by a similar amount during winter seasons (Cassotto et al., 2015). Moreover, as showed by Jensen et al. (2016) through analysis of optical images from 1999 to 2013 , it has not exhibited an unusually large change in area $\left(-10.3 \mathrm{~km}^{2} \mathrm{yr}^{-1}\right)$.

Petermann Glacier flows into the Hall Basin in the Nares Strait in northwestern Greenland (Fig. 1b), and has a perennial floating ice tongue of $1280 \mathrm{~km}^{2}$ in area (Hogg et al., 2016). PG is grounded on bedrock $\sim 300 \mathrm{~m}$ below sea level and, thus, is also influenced by the adjacent ocean (Münchow et al., 2014; Hogg et al., 2016). The retreat of the ice stream calving front led to an area decrease of $352 \mathrm{~km}^{2}$ from 1959 to $2008,270 \mathrm{~km}^{2}$ in 2010 , and $130 \mathrm{~km}^{2}$ in 2012 (Johannessen et al., 2013). It is considered a dynamically stable marineterminating glacier despite several grounding line advancing and retreating events between 1992 and 2011, with a terminus retreat rate of $25.2 \mathrm{~m} \mathrm{a}^{-1}$ (Hogg et al., 2016). PG has had an average velocity of $\sim 1100 \mathrm{~m} \mathrm{yr}^{-1}$ at its grounding line since the 1990s (Rignot, 1996; Rignot and Steffen, 2008) and a multi-annual trend (2006-2010) in flow speed of $30 \mathrm{~m} \mathrm{yr}^{-2}$ (Nick et al., 2012). The ice shelf is thicker than $100 \mathrm{~m}$ and it is $15 \mathrm{~km}$ wide, with low resistive stresses along flow due to the limited attachment to the fjord walls, diminishing the velocity response after calving events (Nick et al., 2012).

Nioghalvfjerdsfjorden and Zachariæ Isstrøm are situated in the northeast of Greenland (Fig. 1c and d respectively). The two glaciers together drain more than $10 \%$ of the Greenland Ice Sheet (Rignot and Mouginot, 2012), and their maximum velocities are found near the grounding line. They have exhibited different behaviour in recent years, although located in the same region. 79-G underwent a modest velocity increase of $\sim 150 \mathrm{~m} \mathrm{yr}^{-1}$ between 2001 and 2011 at the grounding line (Khan et al., 2014). In contrast, during the same period, ZI exhibited a much larger increase in speed greater than $600 \mathrm{~m} \mathrm{yr}^{-1}$ (Khan et al., 2014). The ice thinning rates above the grounding line vary from $5.1 \mathrm{~m} \mathrm{yr}^{-1}$ in ZI (2010-2014) to $1.4 \mathrm{~m} \mathrm{yr}^{-1}$ in 79-G (2012-2014) (Mouginot et al., 2015). Between 1999 and 2013, ZI has undergone an average area change of $-26.0 \mathrm{~km}^{2} \mathrm{yr}^{-1}$, due to break off of the ice tongue and is now a tidewater glacier (Khan et al., 2014; Jensen et al., 2016). In contrast, 79-G had a 


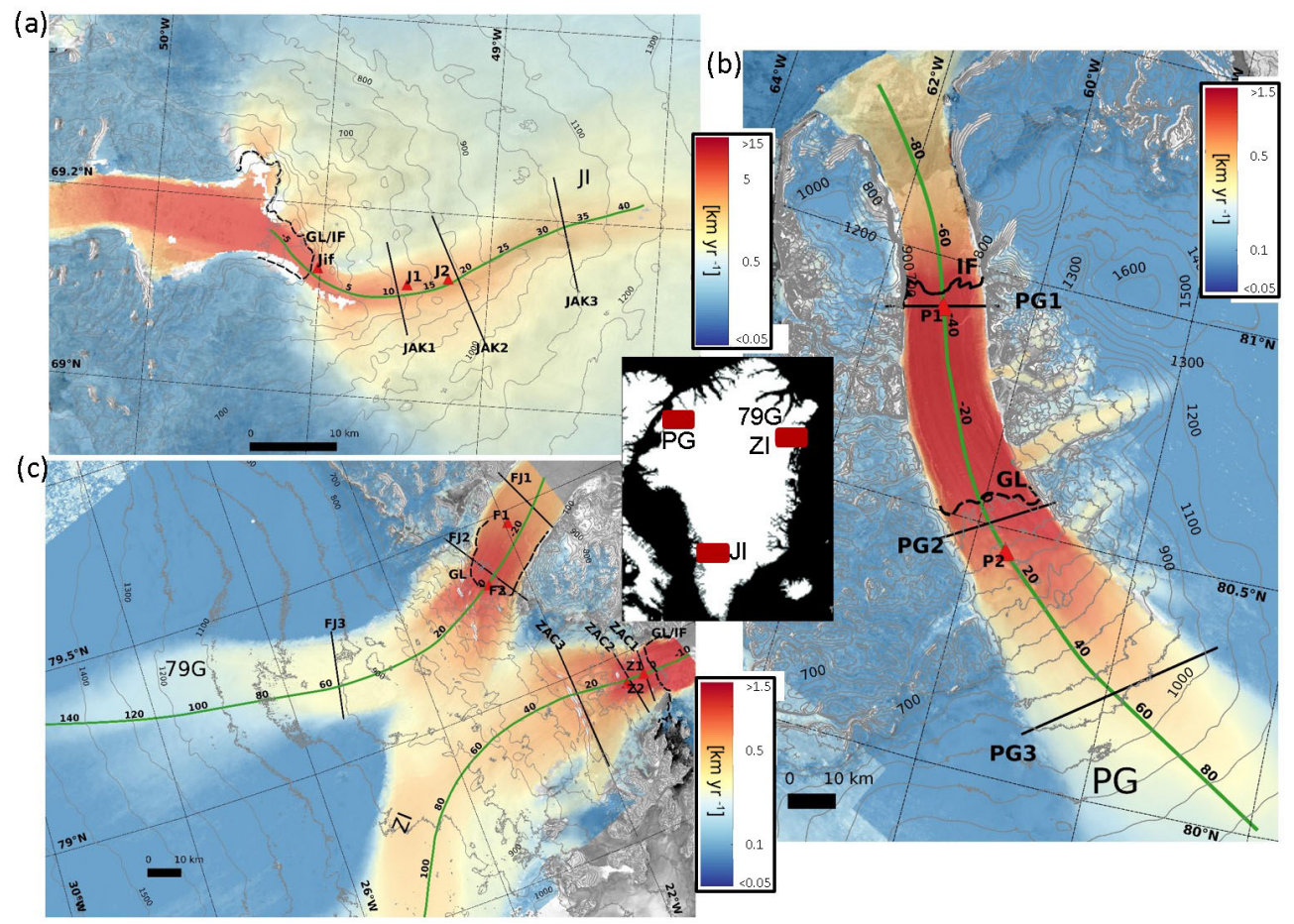

Figure 1. Time-averaged ice velocity magnitude maps for the period October 2014-February 2017: (a) Jakobshavn Isbræ (JI; $69^{\circ} \mathrm{N}, 50^{\circ} \mathrm{W}$ ), (b) Petermann Glacier (PG; $\left.81^{\circ} \mathrm{N}, 62^{\circ} \mathrm{W}\right)$, (c) Nioghalvfjerdsfjorden $\left(79 \mathrm{G} ; 79^{\circ} \mathrm{N}, 20^{\circ} \mathrm{W}\right.$ ), and Zachariæ Isstrøm $\left(\mathrm{ZI} ; 78^{\circ} \mathrm{N}, 20^{\circ} \mathrm{W}\right)$ glaciers, derived from Sentinel-1 SAR images. Velocities are shown on a logarithmic scale and overlaid on a SAR backscatter intensity image and thin grey lines represent elevation. The along-flow profiles are indicated by solid green lines scaled in kilometres, the solid black lines show the across-flow transects, the red triangles represent the locations at which velocity time series are extracted, and the thick solid and dashed black lines represent the ice front locations (IF) and the grounding lines (GL), respectively. The inset figures show the location of each glacier.

much lower average area change during the same period of $-4.7 \mathrm{~km}^{2} \mathrm{yr}^{-1}$ and still retains a small ice shelf (Jensen et al., 2016), although recent ice shelf thinning (Mouginot et al., 2015) may increase vulnerability to break-up in the future.

\section{Data and methodology}

To map ice velocity, we used single look complex (SLC) synthetic aperture radar images acquired in the interferometric wide swath (IW) mode from the Sentinel-1a and Sentinel-1b satellites. Data used in this study were acquired in the period spanning from October 2014 to February 2017 and from October 2016 to February 2017, for Sentinel-1a and Sentinel1b, respectively (Fig. S2 and Table S1 in the Supplement). Each satellite has a repeat cycle of 12 days and 180 degrees orbital phasing difference, resulting in a revisit time of 6 days over the same area after the Sentinel-1b launch. The Sentinel SAR instruments operate at c-band, with a centre frequency of $5.405 \mathrm{GHz}$, corresponding to a wavelength of $5.55 \mathrm{~cm}$. The IW mode has a $250 \mathrm{~km}$ swath and spatial resolution of $5 \mathrm{~m}$ in ground range and $20 \mathrm{~m}$ in azimuth. It has burst synchronization for interferometry and acquires data in three sub-swaths, each containing a series of bursts, which are acquired using the Terrain Observation with Progressive Scans SAR (TOPSAR) imaging technique (Yague-Martinez et al., 2016). We followed the workflow described below to derive 187 ice velocity maps from pairs of Sentinel-1a/b SAR images over Jakobshavn Isbræ, Petermann Glacier, Nioghalvfjerdsfjorden and Zachariæ Isstrøm, using the GAMMA-SAR software (Gamma Remote Sensing, 2015).

We used the SAR intensity tracking technique (Strozzi et al., 2002) to estimate surface ice velocities due to glacier flow, assuming that the ice flow occurs parallel to the surface. This method uses a cross-correlation algorithm applied to image patches (Strozzi et al., 2002; Pritchard et al., 2005; Paul et al., 2015) to estimate offsets between similar features, such as crevasses and radar speckle patterns, in two co-registered SAR images (Table S1). Images were co-registered using the precise orbit information, available 20 days after the image acquisition, establishing a co-registration accuracy of $5 \mathrm{~cm}$ 3-D 1- $\sigma$ (Sentinels POD team, 2013). The elimination of the orbital offsets isolates displacement due to the glacier movement (Strozzi et al., 2002). To estimate ice flow, we then used windows sizes of 350 pixels in ground range $(\sim 1.7 \mathrm{~km})$ and 75 pixels in azimuth $(\sim 1.5 \mathrm{~km})$ for each glacier, to produce 
(a)

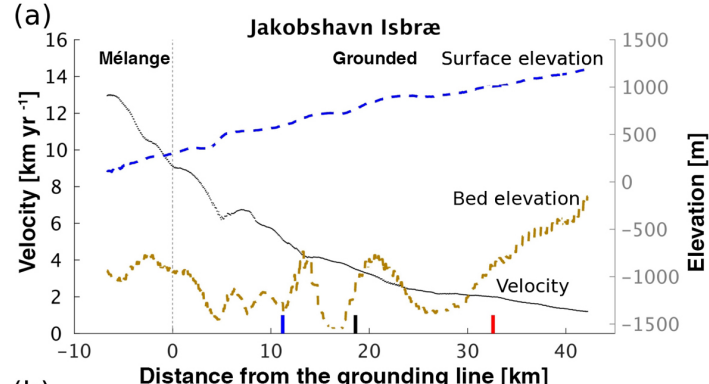

(b)

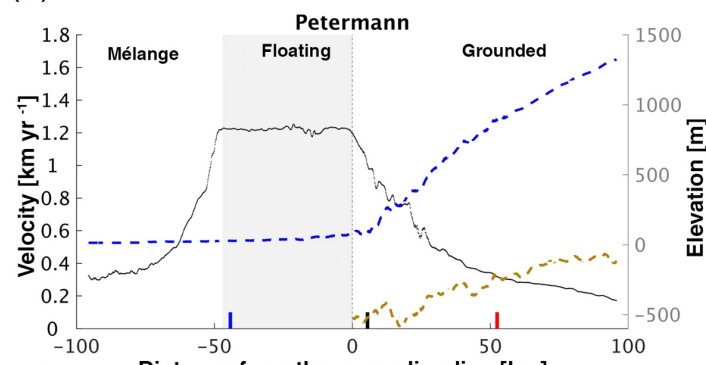

(c)
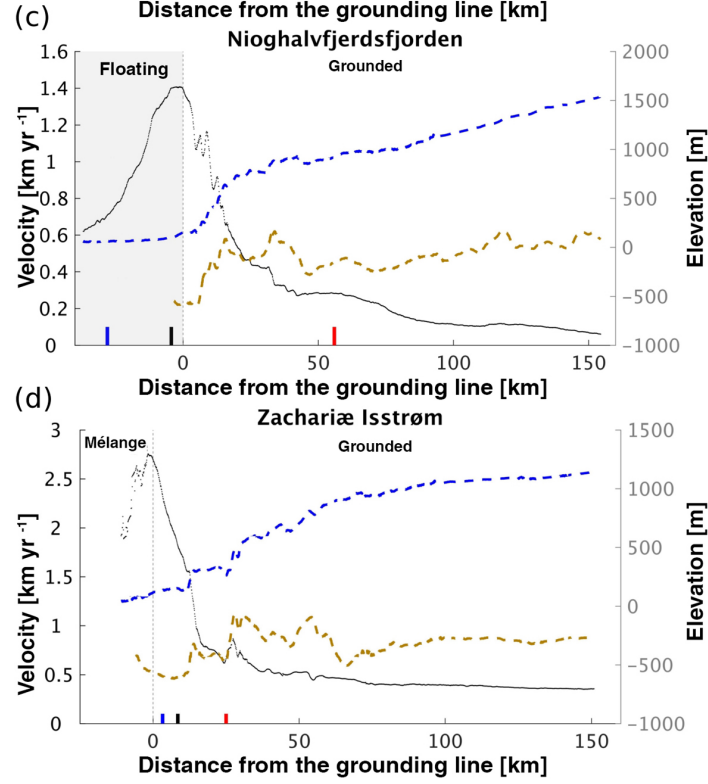

(e)

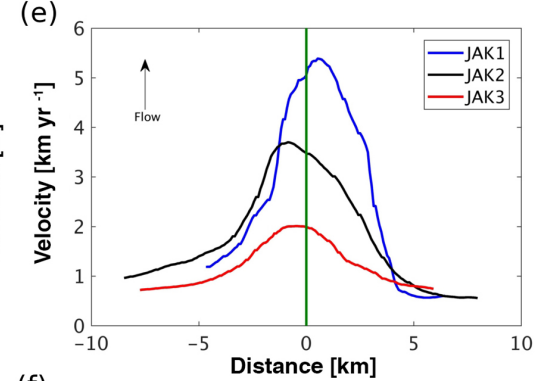

(f)
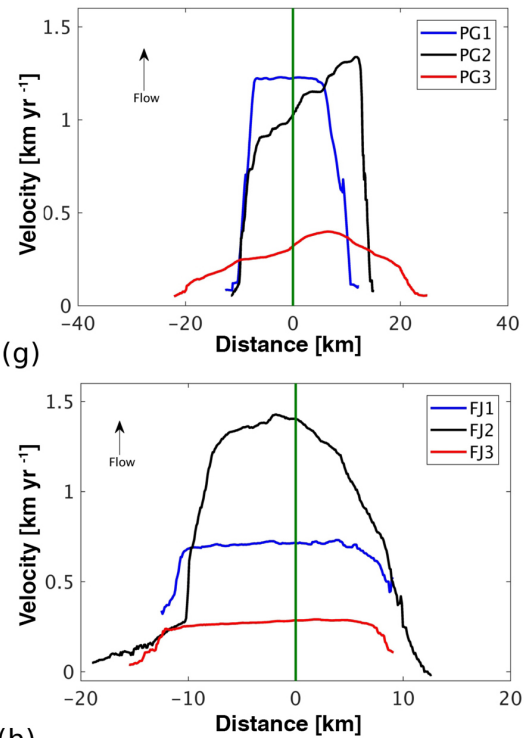

(h)

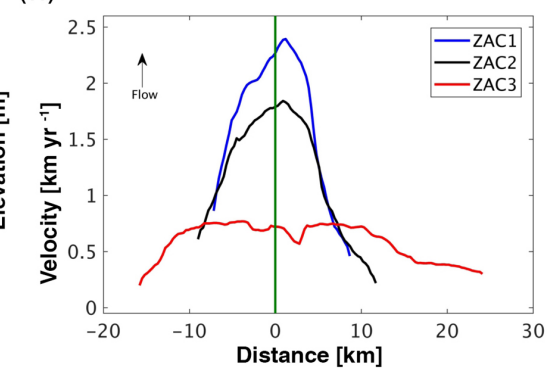

Figure 2. Average velocities (2014-2017) extracted from along- and across-flow profiles of Jakobshavn Isbræ, Petermann Glacier, Nioghalvfjerdsfjorden, and Zachariæ Isstrøm. Panels (a-d) present along-flow profiles of ice velocity (solid black lines), surface elevation from the GIMP DEM (Howat et al., 2014; dashed blue lines) and bed elevation from the IceBridge BedMachine Greenland V2 product (Morlighem et al., 2015; dashed yellow lines). The location of each profile is shown in Fig. 1 (green lines). The grey shaded area represents the floating regions, and the light grey dashed line the ice front positions. The blue, black, and red markers represent the locations of the across-flow profiles. (e-h) show the across-flow velocity profiles (solid white lines in Fig. 1), centred on the main profile (solid green line).

a series of velocity maps with spatial resolution of $388 \mathrm{~m}$ in ground range and $320 \mathrm{~m}$ in azimuth.

Image matches with low certainty, defined as returning a normalized cross-correlation of less than $5 \%$ of its maximum peak, were rejected and the results were then converted into displacement in ground range coordinates using the Greenland Ice Mapping Project (GIMP) digital elevation model (DEM) posted on a $90 \mathrm{~m}$ grid (Howat et al., 2014). Alongand across-track displacement components were combined to determine the displacement magnitude, which was then converted to an estimate of annual velocity using the temporal baseline of each image pair. Final velocity products were posted on $100 \mathrm{~m}$ by $100 \mathrm{~m}$ grids. Post-processing of ice velocity data reduces noise and removes outliers (Paul et al., 2015), so we applied a low-pass filter (moving mean) twice to the data, using a kernel of $1 \mathrm{~km}$ by $1 \mathrm{~km}$, and we reject values where the deviation between the unfiltered and filtered velocity magnitude exceeds $30 \%$. We apply a labelling algo- 


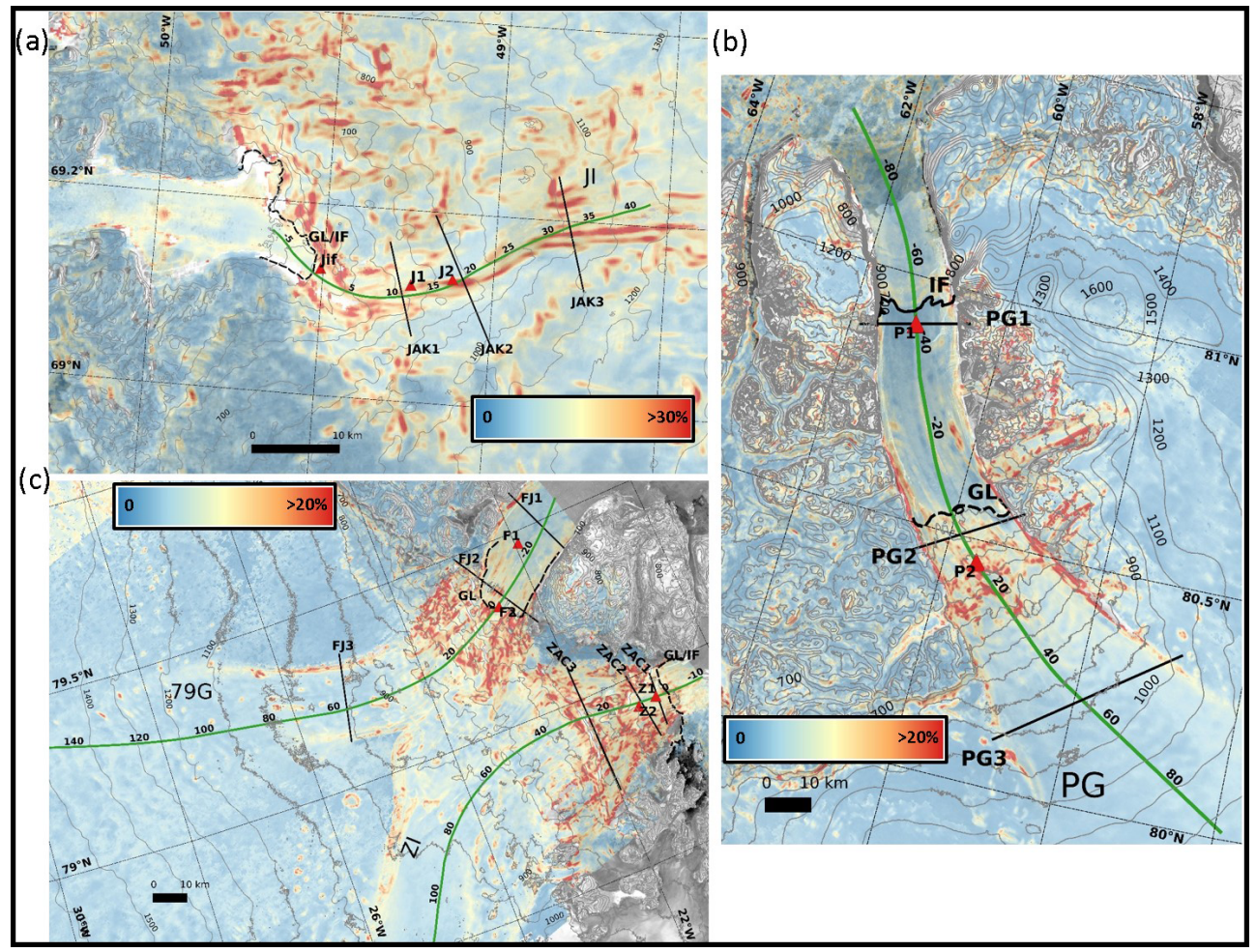

Figure 3. Time-averaged (2014-2017) uncertainty in ice velocity at each site expressed in percentage, based on the signal-to-noise ratio (SNR) for (a) JI, (b) PG, and (c) 79G and ZI.

rithm, based on the image histogram, to identify and classify regions with similar values, excluding isolated pixels with a non-coherent area of velocity values, or where the area of the classified region was smaller than 1/1000th of the processed image size.

Errors in our velocity estimates arise primarily through inexact co-registration of the SAR images, uncertainties in the digital elevation model used in the terrain correction, and fluctuations in ionospheric activity and tropospheric water vapour (Nagler et al., 2015; Hogg et al., 2017). To estimate the accuracy of our Sentinel-1 average velocity data (Figs. 1 and 3) we computed pixel-by-pixel errors based on the signal-to-noise ratio (SNR) of the cross-correlation function (Hogg et al., 2017). The SNR is the ratio between the cross-correlation function peak $\left(C_{\mathrm{p}}\right)$ and the average correlation level $\left(C_{1}\right)$ on the tracking window used to estimate the velocities (de Lange et al., 2007). We then averaged these estimates across all images in our temporal stack to determine the percentage errors associated with our mean velocity maps (Fig. 3). Although in isolated areas the error exceeds $30 \%$, the mean error across the whole imaged area was approximately $10 \%$ for JI, $7 \%$ for PG, and $8 \%$ for $79 \mathrm{G}$ and ZI. Due to the non-uniform flow, lack of stable features, and remaining geometry distortions, the four glaciers exhibit higher errors across their faster flowing and steeper areas, and along the shear margins. Where localized rates of surface elevation change are high, the surface slope may have evolved away from that of the GIMP DEM used in our processing. To assess the sensitivity of our velocity estimates to this effect, we selected the JI site where thinning is most pronounced, and used airborne estimates of elevation change from IceBridge and Pre-Icebridge data acquired from the NASA Airborne Topographic Mapper (ATM) (Studinger, 2014) to update the DEM. We find that in this extreme case, the large thinning rates $\left(\sim 12 \mathrm{~m} \mathrm{yr}^{-1}\right)$ may introduce an additional uncertainty of $200-300 \mathrm{~m} \mathrm{yr}^{-1}$ which may bias the velocity estimates in this region, albeit limited to the first $10 \mathrm{~km}$ upstream of the grounding line (Table S2). Over floating ice tongues, uncompensated vertical tidal displacement may also introduce additional uncertainty into our velocity fields. The sensitivity of our results to this effect was assessed based upon a net $50 \mathrm{~cm}$ tidal displacement over 6-12-day repeat period and a centre swath incidence angle of 35 degrees. We estimate that such a tidal signal would introduce $\sim 20-40 \mathrm{~m} \mathrm{yr}^{-1}$ additional uncertainty into the ground range component of our velocity fields. In the context of this study, this uncertainty does not affect the results at JI or ZI, and it is limited only to the floating sections of $\mathrm{PG}$ and $79 \mathrm{G}$.

To provide an independent evaluation of our ice velocity dataset, we finally compared them (Table S1) to independent estimates derived from TerraSAR-X (TSX) SAR imagery through the speckle tracking technique (Joughin, 


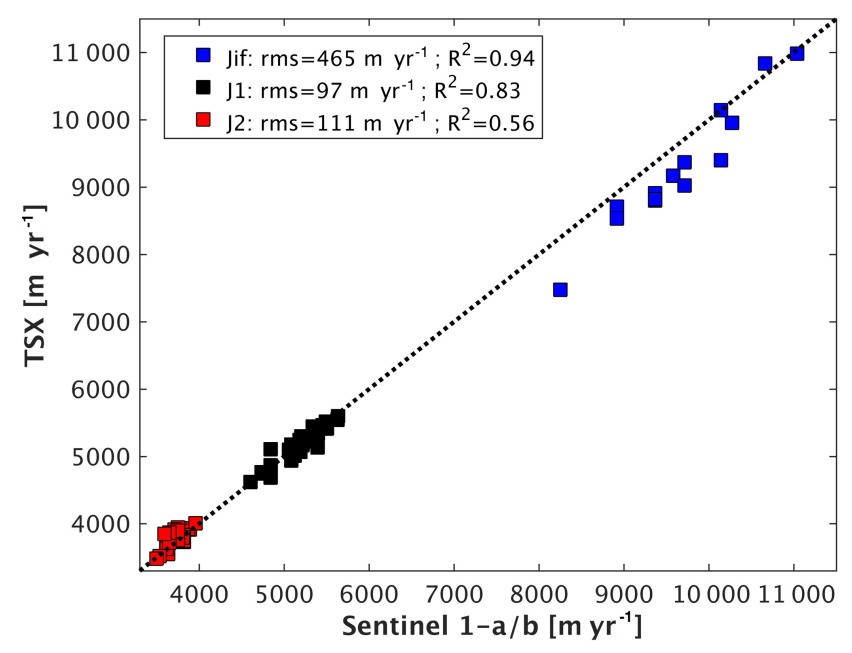

Figure 4. Comparison between co-located and contemporaneous Sentinel $1-\mathrm{a} / \mathrm{b}$ (6 to 12 days average) and TerraSAR-X (11 days average) Jakobshavn Isbræ velocity measurements at Jif, J1 and J2 locations (blue, black and red squares, respectively), together with root mean square (rms) and correlation coefficients $\left(R^{2}\right)$.

2002), which has a repeat period acquisition of 11 days and spatial resolution up to $3 \mathrm{~m}$ (Joughin et al., 2016). The TSX data consist of 444 image pairs covering Jakobshavn Isbræ over the period January 2009 to January 2017, 18 pairs at Petermann Glacier over the period November 2010 to December 2016, and 17 pairs at Nioghalvfjerdsfjorden over the period March 2011 to December 2016. In general, the temporal evolution of the $\mathrm{S} 1-\mathrm{a} / \mathrm{b}$ measurements matches very closely with the TSX estimates. At JI, we are able to compare S1 and TSX datasets at three different locations to assess their consistency (Fig. 4). Even though the flow speed at these sites is high, which typically proves more challenging for feature tracking techniques, we find good agreement between the two datasets, especially at the J1 and $\mathrm{J} 2$ sites, with mean differences of 40 and $76 \mathrm{~m} \mathrm{yr}^{-1}$ respectively. However, nearer to the calving front (site Jif), the S1-a/b measurements tend to give significantly higher velocities than TSX with a mean difference of $489 \mathrm{~m} \mathrm{yr}^{-1}$ ( $5 \%$ of the mean velocity) between the two datasets.

\section{Results and discussion}

We used our complete Sentinel-1a/b dataset (Table S1) to generate contemporary, time-averaged velocity fields at each of our study sites (Fig. 1). To investigate spatial and temporal variations in ice velocity, we then extracted profiles in the along- and across-flow directions, together with time series at fixed glacier locations (Fig. 1). Our velocity profiles in Jakobshavn Isbræ, Petermann Glacier, Nioghalvfjerdsfjorden, and Zachariæ Isstrøm reached maximum mean speeds, along the stacked dataset (averaged over the period 20142017), of approximately $9,1.2,1.4$, and $2.7 \mathrm{~km} \mathrm{yr}^{-1}$, respec-
Table 1. Speedup persistence and seasonal percentage increase in speed relative to winter and annual background for each glacier for the Sentinel 1 dataset. Speedup persistence has an uncertainty of \pm 12 days due to the image acquisition interval of Sentinel 1a.

\begin{tabular}{lrrr}
\hline & $\begin{array}{r}\text { Speedup } \\
\text { persistence }\end{array}$ & $\begin{array}{r}\text { Summer } \\
\text { speedup (\%) }\end{array}$ & $\begin{array}{r}V_{\text {annual }} / \\
V_{\text {winter }}(\%)\end{array}$ \\
\hline \multirow{2}{*}{ II (J1) } & 95 days (2015) & $14 \%$ & $6 \%$ \\
& 80 days (2016) & $9 \%$ & $4 \%$ \\
\hline \multirow{2}{*}{ PG (P1) } & 25 days (2015) & $25 \%$ & $0 \%$ \\
& 55 days (2016) & $17 \%$ & $6 \%$ \\
\hline $79 G(F 2)$ & 45 days (2016) & $10 \%$ & $1 \%$ \\
\hline ZI (Z1) & 45 days (2016) & $18 \%$ & $3 \%$ \\
\hline
\end{tabular}

tively. The location of the velocity maxima varied between glaciers, as a result of their differing geometries. For JI and ZI, neither of which have a significant floating tongue, we find a progressive increase in ice velocity towards the calving front (Fig. 2a and d). For PG, the maximum velocity is reached at the grounding line and remains steady along the $\sim 46 \mathrm{~km}$ of ice tongue (Fig. 2b). In contrast, although $79 \mathrm{G}$ also reaches its maximum velocity close to the grounding line, its speed then diminishes by $\sim 50 \%$ (Fig. 2c) near the ice front location where the ice flow divides into two main portions before it reaches several islands and ice rises (Fig. S1b). Furthermore, it is interesting to note that, despite being located in the same region, the adjacent glacier ZI flows $\sim 60 \%$ faster in comparison. JI, PG, and ZI glaciers show velocity increases progressively downstream across the transverse profiles. The four glaciers, JI, PG, 79G and ZI respectively reduce their maximum velocity to half at distances of $12,22,18$, and $12 \mathrm{~km}$ inland of their grounding lines, highlighting the importance of resolving glacier velocities within their near terminus regions.

Next, we used the Sentinel-1a/b and TerraSAR-X velocities to assess the seasonal and longer-term variations in Jakobshavn Isbræ ice velocity over the period 20092017. Our Sentinel-1a/b velocity estimates at JI resolve clear seasonal velocity fluctuations, superimposed upon longer term decadal-scale variability, which continues observations made by previous satellite instruments (Joughin et al., 2012, 2014). At site $\mathrm{J} 1$ we find an average seasonal change in speed of $750 \mathrm{~m} \mathrm{yr}^{-1}$, or $14 \%$ between 2014 and 2015 and a speedup persistence of 80-95 days, twice as long than those for the other three glaciers (Table 1). Inland, the amplitude of seasonal variability diminishes, to an average of $300 \mathrm{~m} \mathrm{yr}^{-1}(8 \%)$ at $\mathbf{J} 2$. Our near-continuous, decadal-scale record clearly shows that the amplitude of the seasonal signal has evolved through time. At J1, for example, the average seasonal variability in ice speed was $400 \mathrm{~m} \mathrm{yr}^{-1}$ during 2009-2011, increasing by more than a factor of 3 , to 

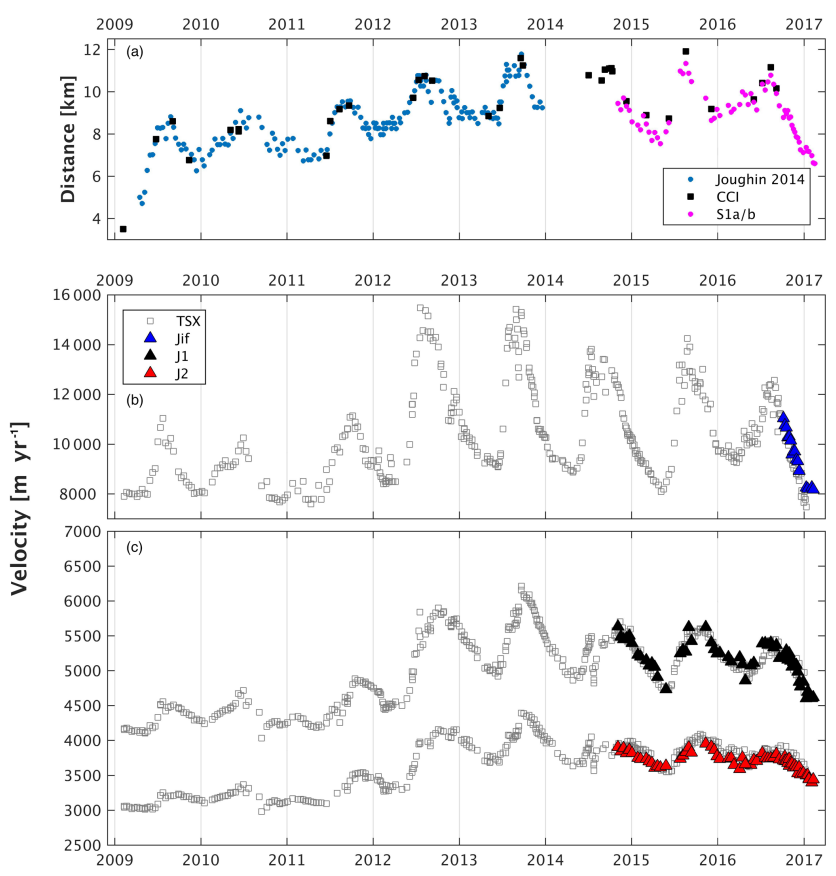

Figure 5. Temporal evolution of Jakobshavn Isbræ (a) ice front position extracted from Joughin et al. (2014), ESA Greenland Ice Sheet Climate Change Initiative (CCI) project (2017), and Sentinel$1 \mathrm{a} / \mathrm{b}$ SAR images represented in blue, black, and magenta dots, respectively, where higher values correspond to ice front retreat. Changes in ice velocity through time is also shown $(\mathbf{b}, \mathbf{c})$, extracted at the locations indicated in Fig. 1. The velocity data derived from TerraSAR-X (11 days - Joughin et al., 2016) are shown as grey squares, and the data from Sentinel $1-\mathrm{a} / \mathrm{b}$ (6 to 12 days) as coloured triangles.

$1400 \mathrm{~m} \mathrm{yr}^{-1}$ between 2012 and 2013 and then diminishing to $750 \mathrm{~m} \mathrm{yr}^{-1}$ between 2015 and 2017.

Turning to the longer term evolution of JI (Fig. 5; time series location shown in Fig. 1), fitting a linear trend to the data suggests an annual acceleration since 2009 of $\sim 218 \mathrm{~m} \mathrm{yr}^{-1}$ at Jif, diminishing inland to $\sim 128 \mathrm{~m} \mathrm{yr}^{-2}$ at $\mathrm{J} 1$, and $\sim 102 \mathrm{~m} \mathrm{yr}^{-2}$ at $\mathrm{J} 2$. Although this provides a simple characterization of the longer-term evolution in ice speed, it is clear from our time series that computing a linear trend does not capture the full decadal-scale variability in ice velocity. In particular, we note that much of the acceleration occurred between 2011 and 2013 (Fig. 5b and c), and since then there has been a notable absence of multi-annual acceleration as earlier records suggest (Joughin et al., 2014). Computing trends in ice velocity since 2012 near the glacier terminus (Jif), for example, shows a modest decline in speed of $321 \mathrm{~m} \mathrm{yr}^{-2}$ over the 5-year period (Fig. 5b). The calving front position migration has been suggested as the trigger to the stresses regimes variations and consequently the main driver to the JI velocity fluctuations (Joughin et al., 2008a, b, 2012, 2014; Bondzio et al., 2017). After a successive and gradually increased rate of ice front retreat un-

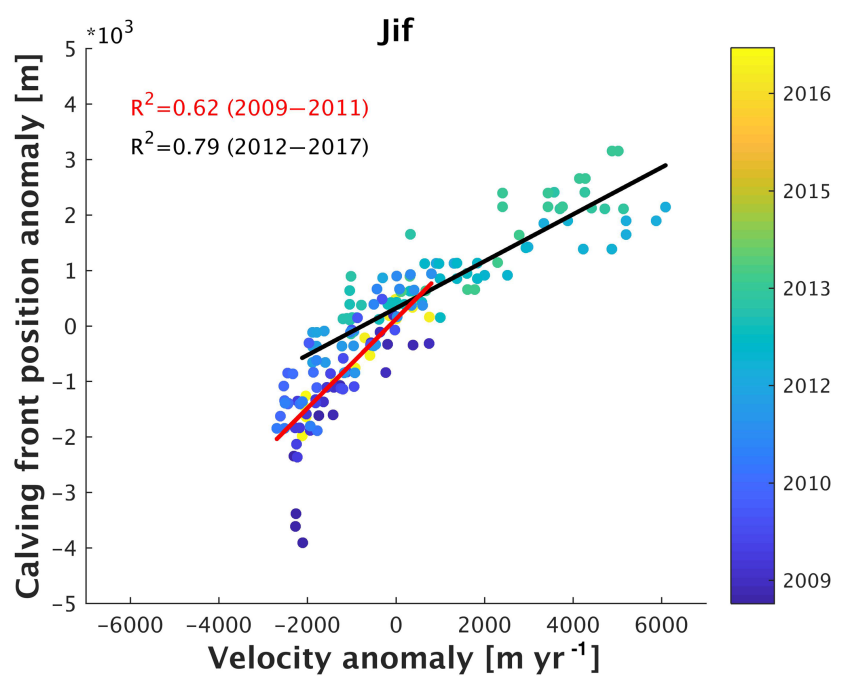

Figure 6. Comparison between Jakobshavn Isbræ ice velocity and calving front position anomalies at the Jif site, $0.8 \mathrm{~km}$ upstream of the calving front, between 2009 and early 2017. Positive values correspond to ice front retreat and speedup respectively. The red and black lines represent the linear regression through the 2009-2011 and 2012-2017 periods, respectively, together with the correlation coefficients $\left(R^{2}\right)$.

til 2012 (Fig. 5a), the JI grounding line is now located on a higher bed location (Joughin et al., 2012; An et al., 2017). This may be acting to stabilize the grounding line, and in turn contribute to the glacier deceleration, although the main cause remains to be determined and further investigations is necessary. We used our observations of calving front position to assess the correlation between ice speed and calving front location, relative to their respective long-term means (Fig. 6). Based on the linear regression (Fig. 6), our dataset indicates correlation coefficients $\left(R^{2}\right)$ of $0.62(2009-2011)$ and 0.79 (2012-2017), and velocity changes by 1100 and $1600 \mathrm{~m} \mathrm{yr}^{-1}$ per kilometre of calving front retreat, respectively.

At Petermann Glacier we extracted two velocity time series at $\mathrm{P} 1$, located $\sim 45 \mathrm{~km}$ downstream of the grounding line and close to the calving front of the ice tongue; and $\mathrm{P} 2, \sim 10 \mathrm{~km}$ upstream of the grounding line. These locations were chosen to examine any differences in velocity evolution over the grounded and floating portions of the glacier. Our P1 time series starts in early 2015 because it is not covered by the TerraSAR-X dataset (Fig. 7a). We observe that, in general, ice at P1 flows $\sim 400 \mathrm{~m} \mathrm{yr}^{-1}$ faster than P2. Fitting a linear trend to the longer $\mathrm{P} 2$ dataset indicates no significant trend in ice velocity since 2011, although the precision of this trend is hampered by the sparse data coverage during the early part of this period. Continued monitoring by Sentinel-1 will improve our confidence in resolving any decadal-scale variability. The improvement in temporal sampling provided by Sentinel-1 at this site is clear (Fig. 7a) and allows us to resolve the seasonal cycle in velocity since 2015 , and helps to 

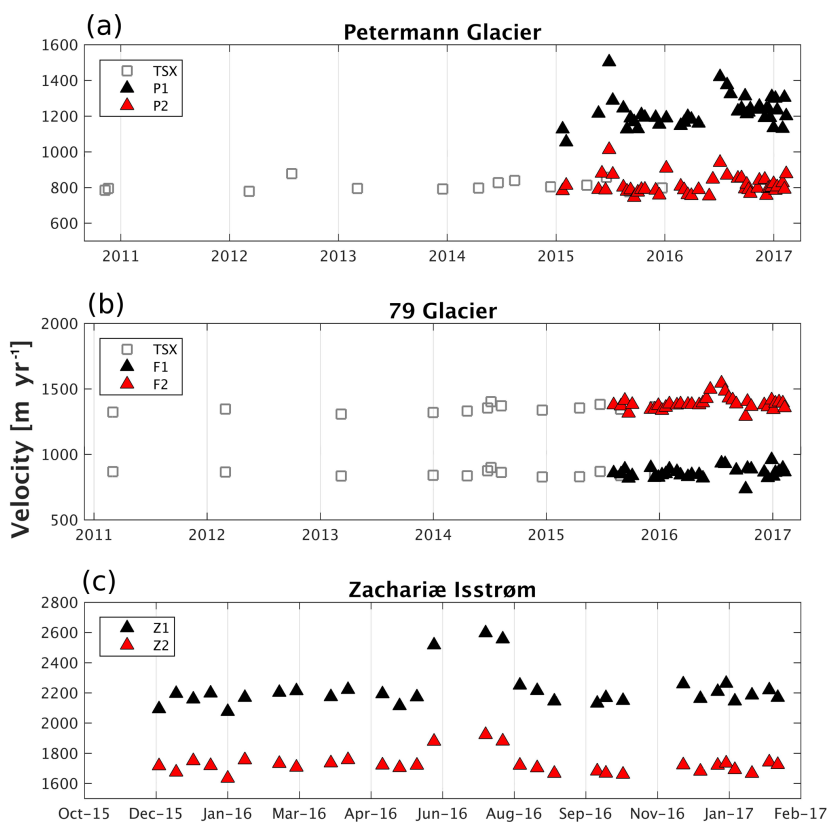

Figure 7. Temporal evolution of ice velocity at the locations indicated in Fig. 1 over (a) Petermann Glacier, (b) Nioghalvfjerdsfjorden and (c) Zachariæ Isstrøm. The data derived from TerraSAR-X (11 days - Joughin et al., 2016) and Sentinel 1-a/b (6 to 12 days) are represented as grey squares and coloured triangles, respectively.

delimit the duration of the speedup period. At P1, we detect a seasonal change in speed of $\sim 300 \mathrm{~m} \mathrm{yr}^{-1}$, equivalent to a $25 \%$ increase relative to its winter velocity (Table 1). Despite the high seasonal change, the relation between P1's annual mean and winter velocity is $0 \%$, likely due to the short speedup period (25 days - Table 1). This provides further evidence of a seasonal velocity cycle which has been observed at both Petermann and other glaciers in this region, and is understood to be predominantly controlled by changes in basal traction, and induced by penetration of surface melt water to the bed (Nick et al., 2012; Moon et al., 2014, 2015). This is further supported by our analysis of changes in calving front position (Fig. S1a), which shows that, in contrast to JI, seasonal acceleration does not coincide with ice front retreat. Specifically, we found that during the summers of 2015 and 2016, the calving front of PG advanced $\sim 1 \mathrm{~km}$ during the speedup (Fig. S1a). These observations are consistent with previous modelling results, which did not find evidence of acceleration driven by large calving events in 2010 and 2012 (Nick et al., 2012; Münchow et al., 2014), suggesting that the ice shelf exerts low backstress on the glacier. More recently, we note that since September 2016 PG has developed a new crack near the ice front, which has continued to grow in length up to the present day.

At 79-G, we again extracted velocity time series over the ice shelf (F1, $\sim 20 \mathrm{~km}$ downstream of the grounding line) and at the grounding line (F2). In contrast to PG and due to the steeper surface gradient upstream of the grounding line
(Fig. 2c), ice flow is slower on the floating tongue than at the grounding line location (Fig. 7b). We observe a seasonal speedup of $\sim 10 \%$ at F2 during summer 2016 (Table 1), although evidence of the same acceleration on the ice shelf is not clear given the magnitude of the signal and the precision of our data. Fitting a linear trend to our data returns an annual change in velocity of $15 \mathrm{~m} \mathrm{yr}^{-2}$ since 2011 , although assessing the significance of this result is difficult given the limited data sampling early in the period. Turning to Zachariæ Isstrøm, we extract time series at two locations slightly upstream of the grounding line in order to observe different temporal responses between them (Fig. 7c). At this glacier, no observations are available within the TSX dataset and so our time series is limited to the period December 2015 to January 2017. Nonetheless, like its neighbour ZI, we again find evidence of a summer speedup during 2016, equating to around $400 \mathrm{~m} \mathrm{yr}^{-1}$, or $18 \%$ (Table 1). Given the short period of observations we do not attempt to derive a longer-term trend in ice velocity at this site.

We compared our estimates to the results of previous studies to assess the level of stability relative to past work. At Petermann, we have observed increases in ice velocity of $\sim 10 \%$ at $\mathrm{P} 1$ and $\sim 8 \%$ at $\mathrm{P} 2$ between the $2015 / 2016$ and 2016/2017 winters, matching in percentage with the observations made by Münchow et al. (2016) between 2013/14 and 2015/16. Furthermore, the Sentinel-1a/b dataset indicates a multi-annual acceleration of $\sim 32 \mathrm{~m} \mathrm{yr}^{-2}$ between 2015-2017 at P1, which is similar to the $\sim 30 \mathrm{~m} \mathrm{yr}^{-2}$ reported by Nick et al. (2012) based upon observational measurements over a longer period, from 2006 to 2010. The same authors also show seasonal variations of $\sim 20-25 \%$ over the same location, similar to the $\sim 22 \%$ shown by the Sentinel-1 dataset. At 79-G, Mouginot et al. (2015) showed a speedup of $8 \%$ from 1976 to 2014 with the main changes occurring after 2006, similar to our estimates which also suggest a slight multi-year trend of $\sim 16 \mathrm{~m} \mathrm{yr}^{-2}(\sim 8 \%)$ for F2 between 2015 and 2017. Zachariæ Isstrøm shows seasonal variation up to $15 \%$ between 2015 and 2017 in the Sentinel1 dataset, agreeing with seasonal variation up to $20 \%$ estimated by Mouginot et al. (2017) using Landsat- 8 optical images during 2014-2016. Overall, our Sentinel 1 results shows a close agreement with previous studies using different techniques and demonstrated to be a powerful tool for monitoring the cryosphere.

\section{Conclusions}

We have presented a new, high temporal resolution record of ice velocity evolution for four important, high discharge marine-based glaciers in Greenland, updated to the present day (October 2014 to February 2017). Using SAR data acquired by the Sentinel-1a/b constellation, with its $250 \mathrm{~km}$ wide swath and frequent revisit time, we have produced 187 velocity maps, which, in combination with 479 maps from 
the TerraSAR-X satellite, provide detailed spatial and temporal coverage of these key sites. Importantly, the systematic acquisition cycle of Sentinel-1a/b, which now provides averaged measurements of all of these sites every 6 days and allows for detailed monitoring of both seasonal and multiannual velocity fluctuations, and allow us to demonstrate the speedup persistence in a higher resolution. The short revisit time of 6 days, made possible since the launch of Sentinel1b in April 2016, particularly benefits the retrieval of velocity signals across fast-flowing regions close to the ice front, due to a reduction in the decorrelation occurring between image pairs. Using this new dataset, we confirm evidence of intra-annual variations in ice velocity and clear seasonal cycles occurring over the past few years at JI, PG, 79G, and ZI. Of the sites studied here, JI exhibits the largest velocity variations, as demonstrated in other studies, which we show are strongly correlated with the evolution of the position of its calving front. However, it is notable that in the last 5 years the longer-term ice speed has started to decrease $\left(321 \mathrm{~m} \mathrm{yr}^{-2}\right)$. This study demonstrates the utility of a new era of operational SAR imaging satellites for building systematic records of ice sheet outlet glacier velocity and its good agreement with TerraSAR-X products, which indicates Sentinel-1 can confidently extend the times series that began with other sensors. Looking to the future, these datasets are key for the timely identification of emerging signals of dynamic imbalance, and for understanding the processes driving ice velocity change.

Data availability. Centre for Polar Observation and Modelling: Sentinel-1 Near Real Time Ice Velocity, available at: http://www. cpom.ucl.ac.uk/csopr/iv, last access: 11 June 2018.

Supplement. The supplement related to this article is available online at: https://doi.org/10.5194/tc-12-2087-2018-supplement.

Competing interests. The authors declare that they have no conflict of interest.

Acknowledgements. This work was led by the NERC Centre for Polar Observation and Modelling, supported by the Natural Environment Research Council (cpom300001), with the support of a grant (4000107503/13/I-BG), and the European Space Agency. Anna E. Hogg is funded by the European Space Agency's support of Science Element program and an independent research fellowship (4000112797/15/I-SBo). Adriano Lemos was supported by CAPES-Brazil PhD scholarship. The NASA MEaSUREs program (NASA grantsNNX08AL98A and NNX13AI21A) supported Ian Joughin's contribution. All data are freely available for download at http://www.cpom.ucl.ac.uk/csopr/iv/ (last access: 11 June 2018). We thank the editor Andreas Vieli, and the two reviewers, Rachel Carr and an anonymous referee, for their comments, which helped to improve the manuscript.

Edited by: Andreas Vieli

Reviewed by: Rachel Carr and one anonymous referee

\section{References}

An, L., Rignot, E., Elieff, S., Morlighem, M., Millan, R., Mouginot, J., and Paden, J.: Bed elevation of Jakobshavn Isbræ, West Greenland, from high-resolution airborne gravity and other data, Geophys. Res. Lett., 44, 3728-3736, https://doi.org/10.1002/2017GL073245, 2017.

Armstrong, W. H., Anderson, R. S., and Fahnestock, M. A.: Spatial Patterns of Summer Speedup on South Central Alaska Glaciers, Geophys. Res. Lett., 44, 9379-9388, https://doi.org/10.1002/2017GL074370, 2017.

Bondzio, J. H., Morlighem, M., Seroussi, H., Kleiner, T., Rückamp, M., Mouginot, J., and Humbert, A.: The mechanisms behind Jakobshavn Isbrae's acceleration and mass loss: a 3D thermomechanical model study, Geophys. Res. Lett., 44, 6252-6260, https://doi.org/10.1002/2017GL073309, 2017.

Carr, J. R., Stokes, C. R., and Vielli, A.: Threefold increase in marine-terminating outlet glacier retreat rates across the Atlantic Arctic: 1992-2010, Ann. Glaciol., 58, 72-91, https://doi.org/10.1017/aog.2017.3, 2017.

Cassotto, R., Fahnestock, M., Amundson, J. M., Truffer, M., and Joughin, I.: Seasonal and interannual variations in ice melange and its impact on terminus stability, Jakobshavn Isbræ, Greenland, J. Glaciol., 61, 76-88, https://doi.org/10.3189/2015JoG13J235, 2015.

Dehecq, A., Gourmelen, N., and Trouve, E.: Deriving large-scale glacier velocities from a complete satellite archive: Application to the Pamir-Karakoram-Himalaya, Remote Sens. Environ., 162, 55-66, https://doi.org/10.1016/j.rse.2015.01.031, 2015.

de Lange, R., Luckman, A., and Murray, T.: Improvement of satellite radar feature tracking for ice velocity derivation by spatial frequency filtering, IEEE Trans. Geosci. Remote Sens., 45, 2309-2318, https://doi.org/10.1109/TGRS.2007.896615, 2007.

Enderlin, E. M., Howat, I. M., Jeong, S., Noh, M.-J., Angelen, J. H. van, and van den Broeke, M. R.: An improved mass budget for the Greenland ice sheet, Geophys. Res. Lett., 41, 1-7, https://doi.org/10.1002/2013GL059010, 2014.

European Space Agency (ESA): Greenland Ice Sheet Climate Change Initiative (CCI) project: Greenland calving front locations v.3.0, available at: http://products.esa-icesheets-cci.org/ products/details/greenland_calving_front_locations_v3_0.zip/ (last access: 11 June 2018), 2017.

Fahnestock, M., Scambos, T., Moon, T., Gardner, A., Haran, T., and Klinger, M.: Rapid large-area mapping of ice flow using Landsat 8, Remote Sens. Environ., 185, 84-94, https://doi.org/10.1016/j.rse.2015.11.023, 2016.

Felikson, D., Bartholomaus, T. C., Catania, G. A., Korsgaard, N. J., Kjær, K. H., Morlighem, M., and Nash, J. D.: Inland thinning on the Greenland ice sheet controlled by outlet glacier geometry, Nat. Geosci., 10, 366-369, https://doi.org/10.1038/ngeo2934, 2017.

GAMMA Remote Sensing: Sentinel-1 processing with GAMMA software, Version 1.2, 2015. 
Gladish, C. V., Holland, D. M., Rosing-Asvid, A., Behrens, J. W., and Boje, J.: Oceanic Boundary Conditions for Jakobshavn Glacier. Part II: Provenance and Sources of Variability of Disko Bay and Ilulissat Icefjord Waters, 1990-2011, J. Phys. Oceanogr., 45, 33-63, https://doi.org/10.1175/JPO-D-14-0045.1, 2015.

Hogg, A., Shepherd, A., and Gourmelen, N.: A first look at the performance of Sentinel-1 over the West Antarctic Ice Sheet, FRINGE 2015, Frascati, Italy, 23-27 March, 2015.

Hogg, A. E., Shepherd, A., Gourmelen, N., and Engdahl, M.: Grounding line migration from 1992 to 2011 on Petermann Glacier, North-West Greenland, J. Glaciol., 62, 1-11, https://doi.org/10.1017/jog.2016.83, 2016.

Hogg, A. E., Shepherd, A., Cornford, S. L., Briggs, K. H., Gourmelen, N., Graham, J., and Wuite, J.: Increased ice flow in Western Palmer Land linked to ocean melting, Geophys. Res. Lett., 44, 1-9, https://doi.org/10.1002/2016GL072110, 2017.

Holland, D. M., Thomas, R. H., Young, B. De, Ribergaard, M. H., and Lyberth, B.: Acceleration of Jakobshavn Isbræ triggered by warm subsurface ocean waters, Nat. Geosci., 1, 1-6, https://doi.org/10.1038/ngeo316, 2008.

Howat, I. M., Box, J. E., Ahn, Y., Herrington, A., and McFadden, E. M.: Seasonal variability in the dynamics of marineterminating outlet glaciers in Greenland, J. Glaciol., 56, 601613, https://doi.org/10.3189/002214310793146232, 2010.

Howat, I. M., Negrete, A., and Smith, B. E.: The Greenland Ice Mapping Project (GIMP) land classification and surface elevation data sets, The Cryosphere, 8, 1509-1518, https://doi.org/10.5194/tc-8-1509-2014, 2014.

Jensen, T. S., Box, J. E., and Hvidberg, C. S.: A sensitivity study of annual area change for Greenland ice sheet marine terminating outlet glaciers: 1999-2013, J. Glaciol., 62, 1-10, https://doi.org/10.1017/jog.2016.12, 2016.

Johannessen, O. M., Babiker, M., and Miles, M. W.: Unprecedented Retreat in a 50-Year Observational Record for Petermann, Atmos. Ocean. Sci. Lett., 6, 259-265, https://doi.org/10.3878/j.issn.1674-2834.13.0021.1, 2013.

Joughin, I.: Ice-sheet velocity mapping: a combined interferometric and speckle-tracking approach, Ann. Glaciol., 34, 195-201, https://doi.org/10.3189/172756402781817978, 2002.

Joughin, I., Winebrenner, D. P., and Fahnestock, M. A.: Observations of ice-sheet motion in Greenland using satellite radar interferometry, Geophys. Res. Lett., 22, 571-574, https://doi.org/10.1029/95GL00264, 1995.

Joughin, I., Howat, I. M., Fahnestock, M., Smith, B., Krabill, W., Alley, R. B., and Truffer, M.: Continued evolution of Jakobshavn Isbræ following its rapid speedup, J. Geophys. Res.-Earth Surf., 113, 1-14, https://doi.org/10.1029/2008JF001023, 2008a.

Joughin, I., Das, S. B., King, M. A., Smith, B. E., Howat, I. M., and Moon, T.: Seasonal Speedup Along the Western Flank of the Greenland Ice Sheet, Science, 320, 781-784, https://doi.org/10.1126/science.1153288, 2008b.

Joughin, I., Smith, B. E., Howat, I. M., Scambos, T., and Moon, T.: Greenland flow variability from icesheet-wide velocity mapping, J. Glaciol., 56, 415-430, https://doi.org/10.3189/002214310792447734, 2010.

Joughin, I., Smith, B. E., Howat, I. M., Floricioiu, D., Alley, R. B., Truffer, M., and Fahnestock, M.: Seasonal to decadal scale variations in the surface velocity of Jakobshavn Isbræ, Greenland:
Observation and model-based analysis, J. Geophys. Res.-Earth Surf., 117, 1-20, https://doi.org/10.1029/2011JF002110, 2012.

Joughin, I., Smith, B. E., Shean, D. E., and Floricioiu, D.: Brief Communication: Further summer speedup of Jakobshavn Isbræ, The Cryosphere, 8, 209-214, https://doi.org/10.5194/tc-8-2092014, 2014.

Joughin, I., Smith, B., Howat, I., and Scambos, T.: MEaSUREs Multi-year Greenland Ice Sheet Velocity Mosaic, Version 1. Boulder, Colorado USA, NASA National Snow and Ice Data Center Distributed Active Archive Center, https://doi.org/10.5067/QUA5Q9SVMSJG, 2016.

Khan, S. A., Aschwanden, A., Bjørk, A. A., Wahr, J., Kjeldsen, K. K., and Kjær, K. H.: Greenland ice sheet mass balance: a review, Reports on Prog. Phys., IOP Publishing, 4, 292-299, https://doi.org/10.1088/0034-4885/78/4/046801, 2014.

Lucchitta, B. K. and Ferguson, H. M.: Antarctica: measuring glacier velocity from satellite images, Science (New York, N.Y.), 234, 1105-1108, https://doi.org/10.1126/science.234.4780.1105, 1986.

McMillan, M., Leeson, A., Shepherd, A., Briggs, K., Armitage, T. W. K., Hogg, A., and Gilbert, L.: A high resolution record of Greenland mass balance, Geophys. Res. Lett., 43, 1-9, https://doi.org/10.1002/GRL.54619, 2016.

Moon, T., Joughin, I., Smith, B., and Howat, I.: 21st-century evolution of Greenland outlet glacier velocities, Science, 336, 576578, https://doi.org/10.1126/science.1219985, 2012.

Moon, T., Joughin, I., Smith, B., Broeke, M. R., Berg, W. J., Noël, B., and Usher, M.: Distinct patterns of seasonal Greenland glacier velocity, Geophys. Res. Lett., 41, 7209-7216, https://doi.org/10.1002/2014GL061836, 2014.

Moon, T., Joughin, I., and Smith, B.: Seasonal to multiyear variability of glacier surface velocity, terminus position, and sea ice/ice mélange in northern Greenland, J. Geophys. Res.-Earth Surf., 120, 818-833, https://doi.org/10.1002/2015JF003494, 2015.

Morlighem, M., Rignot, E., Mouginot, J., Seroussi, H., and Larour, E.: IceBridge BedMachine Greenland, Version 2. Boulder, Colorado USA, NASA National Snow and Ice Data Center Distributed Active Archive Center, (09/08/2017) https://doi.org/10.5067/AD7B0HQNSJ29, 2015.

Mouginot, J., Rignot, E., Scheuchl, B., Fenty, I., Khazendar, A., Morlighem, M., and Paden, J.: Fast retreat of Zachariæ Isstrøm, northeast Greenland, Science Express, 10.1126 (November), https://doi.org/10.1126/science.aac7111, 2015.

Mouginot, J., Rignot, E., Scheuchl, B., and Millan, R.: Comprehensive Annual Ice Sheet Velocity Mapping Using Landsat-8, Sentinel-1, and RADARSAT-2 Data, Remote Sens., 9, 1-20, https://doi.org/10.3390/rs9040364, 2017.

Münchow, A., Padman, L., and Fricker, H. A.: Interannual changes of the floating ice shelf of Petermann Gletscher, North Greenland, from 2000 to 2012, J. Glaciol., 60, 489-499, https://doi.org/10.3189/2014JoG13J135, 2014.

Münchow, A., Padman, L., Washam, P., and Nicholls, K. W.: The ice shelf of Petermann Gletscher, North Greenland, and its connection to the Arctic and Atlantic Oceans, Oceanography, 29, 84-95, https://doi.org/10.5670/oceanog.2016.101, 2016.

Nagler, T., Rott, H., Hetzenecker, M., Wuite, J., and Potin, P.: The Sentinel-1 Mission: New Opportunities for Ice Sheet Observations, Remote Sens., 7, 9371-9389, https://doi.org/10.3390/rs70709371, 2015. 
Nick, F. M., Luckman, A., Vieli, A., Van Der Veen, C. J., Van As, D., Van De Wal, R. S. W., and Floricioiu, D.: The response of Petermann Glacier, Greenland, to large calving events, and its future stability in the context of atmospheric and oceanic warming, J. Glaciol., 58, 229-239, https://doi.org/10.3189/2012JoG11J242, 2012.

Paul, F., Bolch, T., Kääb, A., Nagler, T., Nuth, C., Scharrer, K., and Van Niel, T.: The glaciers climate change initiative: Methods for creating glacier area, elevation change and velocity products, Remote Sens. Environ., 162, 408-426, https://doi.org/10.1016/j.rse.2013.07.043, 2015.

Pritchard, H., Murray, T., Luckman, A., Strozzi, T., and Barr, S.: Glacier surge dynamics of Sortebræ, east Greenland, from synthetic aperture radar feature tracking, J. Geophys. Res., 110, 113, https://doi.org/10.1029/2004JF000233, 2005.

Rignot, E.: Tidal motion, ice velocity and melt rate of Petermann Gletscher, Greenland, measured from radar interferometry, J. Glaciol., 42, 476-485, 1996.

Rignot, E. and Kanagaratnam, P.: Changes in the Velocity Structure of the Greenland Ice Sheet, Science, 311, 986-990, https://doi.org/10.1126/science.1121381, 2006.

Rignot, E. and Mouginot, J.: Ice flow in Greenland for the International Polar Year 2008-2009, Geophys. Res. Lett., 39, 1-7, https://doi.org/10.1029/2012GL051634, 2012.

Rignot, E. and Steffen, K.: Channelized bottom melting and stability of floating ice shelves, Geophys. Res. Lett., 35, 1-5, https://doi.org/10.1029/2007GL031765, 2008.

Sentinels POD Team: Sentinels POD Service File Format Specifications, European Space Agency, Paris, France, 2013.
Shepherd, A., Ivins, E. R., Geruo, A., Barletta, V. R., Bentley, M. J., Bettadpur, S., and Zwally, H. J.: A Reconciled Estimate of Ice-Sheet Mass Balance, Science, 338, 1183-1189, https://doi.org/10.1126/science.1228102, 2012.

Strozzi, T., Luckman, A., Murray, T., Wegmuller, U., and Werner, C. L.: Glacier motion estimation using SAR offset-tracking procedures, IEEE T. Geosci. Remote Sens., 40, 2384-2391, https://doi.org/10.1109/TGRS.2002.805079, 2002.

Studinger, M. S.: IceBridge ATM L4 Surface Elevation Rate of Change, Version 1, Greenland subset. Boulder, Colorado USA, NASA National Snow and Ice Data Center Distributed Active Archive Center, https://doi.org/10.5067/BCW6CI3TXOCY, 2014.

Tedesco, M., Fettweis, X., Mote, T., Wahr, J., Alexander, P., Box, J. E., and Wouters, B.: Evidence and analysis of 2012 Greenland records from spaceborne observations, a regional climate model and reanalysis data, The Cryosphere, 7, 615-630, https://doi.org/10.5194/tc-7-615-2013, 2013.

van den Broeke, M., Bamber, J. L., Ettema, J., Rignot, E., Schrama, E., van de Berg, W. J., and Wouters, B.: Partitioning recent Greenland mass loss, Science, 326, 984-986, https://doi.org/10.1126/science.1178176, 2009.

van de Wal, R. S. W., Smeets, C. J. P. P., Boot, W., Stoffelen, M., van Kampen, R., Doyle, S. H., Wilhelms, F., van den Broeke, M. R. Reijmer, C. H., Oerlemans, J., and Hubbard, A.: Self-regulation of ice flow varies across the ablation area in south-west Greenland, The Cryosphere, 9, 603-611, https://doi.org/10.5194/tc-9603-2015, 2015.

Yague-Martinez, N., Prats-Iraola, P., Gonzalez, F. R., Brcic, R., Shau, R., Geudtner, D., and Bamler, R.: Interferometric Processing of Sentinel-1 TOPS data, IEEE T. Geosci. Remote Sens., 54, 2220-2234, https://doi.org/10.1109/TGRS.2015.2497902, 2016. 